\title{
EFFECT OF ADDITION OF TEMULAWAK EXTRACT (Curcuma xanthorriza) ON ARTIFICIAL FEED ON GURAMI FISH GROWTH (Osphronemus goramy)
}

\author{
Dian Ananda ${ }^{1}$, Saptono Waspodo ${ }^{1}$, Baiq Hilda Astriana ${ }^{1}$ \\ ${ }^{1}$ Aquaculture Study Program, Faculty of Agriculture, University of Mataram \\ Jl. Pendidikan No. 37 Mataram, NTB
}

*Correspondence:

diananada633@gmail.com

Received : 2021-12-21

Accepted : 2021-12-22

Keywords :

Temulawak Extract, Growth, Gourami

\begin{abstract}
The problem with gouramy cultivation was slow growth due to the short intestines of gouramy so that the absorption of feed takes longer and less. Several previous studies used temulawak in the form of flour, extract, oil which was applied to carp, tilapia, milkfish, catfish. The addition of extract, temulawak flour to the feed gave an increase in growth both in length and weight in the test fish. The purpose of this study was to determine whether or not the effect of temulawak extract on the growth of gouramy fish. This research was conducted for 45 days. This research was conducted by experimental method using a completely randomized design (CRD) with 5 treatments (P) 3 times replication (U), in order to obtain 15 experimental units. Treatment 0 Control (without temulawak extract), Treatment 1 Provision of temulawak extract with a concentration of $14 \% / \mathrm{kg}$ feed, Treatment P2 Administration of temulawak extract with a concentration of $16 \% / \mathrm{kg}$ feed, treatment P3 Administration of temulawak extract with a concentration of $18 \% / \mathrm{kg}$ feed, and treatment P4 administration of temulawak extract with a concentration of $20 \% / \mathrm{kg}$ feed. The results showed that in the PO treatment the absolute weight gain was 0.78 grams, in the $P 1$ treatment the absolute weight was 0.58 grams, the $\mathrm{P} 2$ treatment was 0.33 grams, the $\mathrm{P} 3$ treatment was 0.37 grams, and in the $\mathrm{P} 4$ treatment it was obtained The result of absolute weight gain was 0.39 grams. The results showed the absolute length increase ranged from $0.35-0.57 \mathrm{~cm}$. It can be concluded that the addition of temulawak extract to the commercial feed of carp has no significant effect on absolute weight, absolute length, survival rate and feed efficiency level.
\end{abstract}

\section{INTRODUCTION}

Gouramy was one of the freshwater consumption fish commodities that have high economic value. Gourami has promising prospects for cultivation, both on a small and large scale, because the cultivation of gouramy was supported by factors, namely a higher selling price compared to freshwater fish. others, so that it was relatively more economically 
Journal of Fish Health Vol. 1 (2) - Dec 2021

Ananda et al. (2021)

https://doi.org/10.29303/jfh.v1i2.531

profitable. In addition, market demand has increased from 9,004 tons, 9,327 tons and 13,339 in three consecutive years, resulting in greater market opportunities (Agromedia, 2007).

The problem with gouramy cultivation was slow growth due to the short intestine of gouramy (Kapoor et al., 1975 in Affandi, 1993), so that the absorption of feed was long and little. The process of processing feed in the stomach for a long-time result in the long conversion of feed into meat which results in the slow growth of fish, both in terms of weight and length of fish. To overcome this problem, chemical drugs or antibiotics are usually given. Continuous administration of chemical drugs or antibiotics will cause problems such as the emergence of bacterial resistance, the presence of residues in the fish body, and polluting the environment which can eventually kill non-target organisms (Wu et al., 1981 in Setyo, 2017).

Another solution that can be used to overcome these problems was to use natural ingredients. One of these ingredients was ginger. Substances contained in temulawak are curcumin, fiber, starch, potassium, oxalate, essential oils, and flavonoids. These substances function as antimicrobial or antibacterial, prevent blood clots, anti-inflammation, launch metabolism and function of body organs (Directorate General of POM, 2000 in Setyo, 2017).

Several previous studies used temulawak in the form of flour, extract, oil which was applied to carp, tilapia, milkfish, catfish. The addition of extract, temulawak flour to the feed gave an increase in growth both in length and weight in the test fish. Research on the use of temulawak has been carried out by Prabowo (2017) on milkfish (Chanos chanos). Insana (2015) also conducted research on the substitution of temulawak flour in tilapia (Oreochromis niloticus) fingerlings. So, this study was conducted to determine whether or not the effect of temulawak extract on the growth of gouramy fish. Therefore, this study was conducted to apply the temulawak extract and to determine whether or not the effect of temulawak extract on the growth of carp.

\section{METHODOLOGY}

Research Time and Place

This research was carried out for 45 days, starting from February 20 to April 5, 2020 at the Aquaculture Laboratory, Aquaculture Study Program, University of Mataram. The extract was made at the Analytical MIPA Laboratory, Faculty of Mathematics and Natural Sciences, University of Mataram.

\section{Research Design}

This research was conducted by experimental method using a completely randomized design (CRD) with 5 treatments $(P) 3$ times replication $(U)$, in order to obtain 15 experimental units. The aspect studied was to see the effect of adding temulawak extract to commercial feed with the brand HI-PRO-VITE 788. The doses used were as follows:

Treatment $0=$ Control (without ginger extract)

Treatment 1 = Giving Temulawak extract with a concentration of $14 \% / \mathrm{kg}$ feed Treatment 2 = Giving temulawak extract with a concentration of $16 \% / \mathrm{kg}$ feed Treatment 3 = Giving temulawak extract with a concentration of $18 \% / \mathrm{kg}$ feed Treatment $4=$ Giving temulawak extract with a concentration of $20 \% / \mathrm{kg}$ feed 
Journal of Fish Health Vol. 1 (2) - Dec 2021

Ananda et al. (2021)

https://doi.org/10.29303/jfh.v1i2.531

\section{Research procedure}

Container Preparation

The container used in this study was a container measuring $30 \times 30 \times 30 \mathrm{~cm}^{3}$ with a volume of 27 liters. Before use, the container must be washed with soap, then the container was dried. Before use, the container must be stored approximately 1 time 24 hours so that the material used during washing was lost (evaporated).

\section{Test Animal Preparation}

The fish used was carp seed which was $4-5 \mathrm{~cm}$ long. Fish were obtained from the Batu Kumbung Fish Seed Center, Lingsar District, West Lombok Regency. Gouramy seeds are fish seeds that are directly spawned by the Batu Kumbung Fish Seed Center which are approximately 1 month old.

\section{Test Animal Acclimatization}

Before being used for test animals in research, carp first acclimatized so that the test animals get used to the new environment and are not stressed. Acclimatization was done by placing the fish in a plastic bag on the surface of the water for 5 minutes or until you see dew in the plastic bag, then open the plastic bag and let the fish come out by itself.

\section{Making Temulawak Extract}

Temulawak rhizome used as much as $5 \mathrm{~kg}$ and selected that are not rotten or not damaged. Then the ginger was cleaned and washed, then sliced thinly and dried in the sun to dry. After that, the ginger was ground to a powder form. Extraction with ethanol by means of ginger powder wrapped in filter paper and put into an extraction glass. Extraction was carried out using $96 \%$ ethanol as solvent and allowed to soak for \pm 3 days. This process was carried out several times with the replacement of ethanol. After that, evaporation was carried out using an evaporator to obtain the ginger extract.

\section{Making Temulawak Solution}

To determine the concentration to be used, the extract with a concentration of $100 \%$ was then diluted using distilled water with each desired concentration of $14 \%, 16 \%, 18 \%$, and $20 \%$ using the following formula (Gunawan and Mulyani, 2004).

Description,

$$
\mathrm{M}_{1} \times \mathrm{V}_{1}=\mathrm{V}_{2} \times \mathrm{M}_{2}
$$

$\mathrm{V}_{1} \quad=$ volume of solution to be diluted $(\mathrm{ml})$

M1 = concentration of available temulawak extract (\%)

$\mathrm{V}_{2} \quad$ = desired volume of solution (water + extract) $(\mathrm{ml})$

$\mathrm{M}_{2}$ = concentration of ginger extract to be made (\%)

\section{Test Feed Preparation}

The feed used was carp feed obtained from carp cultivators. Before use, $1 \mathrm{~kg}$ of feed was weighed and then sprayed with ginger solution. The feed that has been sprayed with the temulawak solution was stirred until evenly mixed then the feed was dried in an oven at $40^{\circ} \mathrm{C}$ (until dry) and after that the feed was ready for use.

\section{Test Animal Care}

The maintenance of the test fish was carried out for 45 days. Fish are kept at a density of 10 individuals per aquarium. During rearing the fish are given the same amount of feed 
Journal of Fish Health Vol. 1 (2) - Dec 2021

Ananda et al. (2021)

https://doi.org/10.29303/jfh.v1i2.531

according to the initial biomass of the fish, feed was given three times a day, morning, afternoon and evening, siphoning was done once a day to keep the water clean.

Observed Parameters

Absolute Weight Growth

Absolute growth was growth in an organism being reared which was measured at the end of rearing. The absolute growth rate during maintenance was calculated using the Effendie (1979) formula in Hartini et al., (2013) as follows:

Description:

$$
W=W t-W_{0}
$$

$\mathrm{W}=$ Growth absolute weight of fish kept (g)

$\mathrm{Wt}=$ Fish weight at the end of rearing $(\mathrm{g})$

Wo $=$ Fish weight at the beginning of rearing $(g)$

Absolute Length Growth

Description:

$$
L=P t-P o
$$

$P=$ growth in absolute length of fish kept $(\mathrm{cm})$

$\mathrm{Pt}=$ Length of fish at the end of rearing $(\mathrm{cm})$

$\mathrm{Po}=$ Length of fish at the beginning of maintenance $(\mathrm{cm})$

Survival Rate

The survival rate of fish during rearing was calculated using the formula Effendi (1979) in Hartini et al. (2013) are as follows:

$$
\mathrm{SR}=\frac{\mathrm{Nt}}{\mathrm{No}} \times 100 \%
$$

Description:

$\mathrm{SR} \quad=$ Survival (\%)

$\mathrm{Nt} \quad=$ Number of fish at the end of rearing (tails)

No $\quad=$ Number of fish at the beginning of stocking (tails)

Feed Efficiency Rate

Feed efficiency was the amount of feed used to increase $1 \mathrm{~kg}$ of fish meat. The formula used to calculate feed efficiency according to (Mulyani et al., 2014)

$$
\mathrm{EP}=\frac{(\mathrm{Wt}+\mathrm{D})-\mathrm{WO}}{\mathrm{F}} \times 100 \%
$$

\section{Description:}

$\mathrm{EP} \quad=$ Feed Efficiency (\%)

$\mathrm{Wt}=$ Total weight of fish at the end of rearing $(\mathrm{g})$

WO = Total weight of fish at the beginning of rearing (g)

$\mathrm{D} \quad=$ Total dead fish weight during maintenance $(\mathrm{g})$

$\mathrm{F} \quad=$ Amount of feed consumed (g) 
Journal of Fish Health Vol. 1 (2) - Dec 2021

Ananda et al. (2021)

https://doi.org/10.29303/jfh.v1i2.531

Water quality

The water quality measured in this study was temperature, degree of acidity $(\mathrm{pH})$, and dissolved oxygen. Measurement of these parameters was carried out at the beginning $(H 1)$, in the middle ( $\mathrm{H} \mathrm{22}$ ) and at the end of maintenance $(\mathrm{H} \mathrm{45)}$. The results of water quality measurements were recorded and analyzed descriptively.

Data analysis

The data obtained were then analyzed using variance (ANOVA) with a 95\% confidence level. If the data shows a real effect, further tests are carried out to determine the best treatment. Water quality data were analyzed descriptively.

\section{RESULT}

\section{Absolute Weight Growth}

Absolute weight was the weight growth of a test fish during the maintenance period and was expressed in $(\mathrm{cm})$. The test fish were kept for 45 days and the data are presented in Figure 4.1.

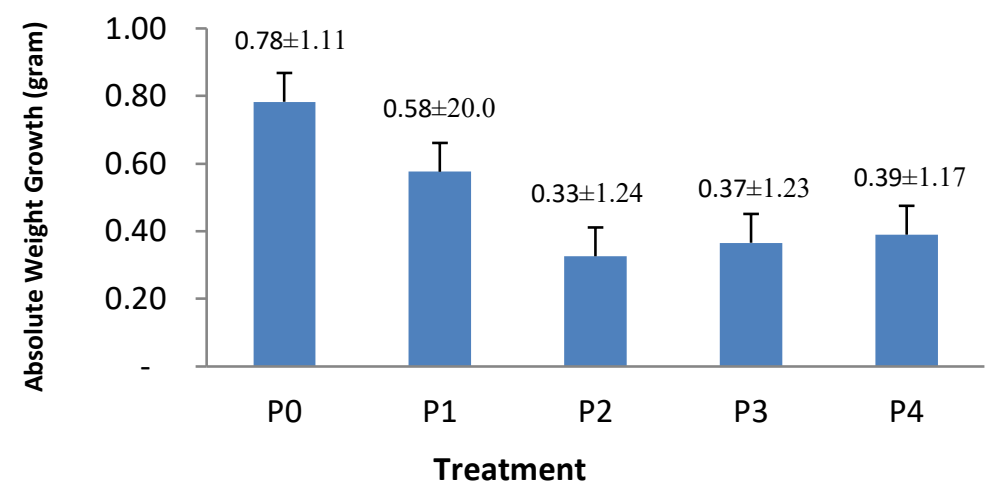

Figure 4.1 Absolute Weight of Gourami

Based on the analysis of variance (ANOVA) test results, it was shown that the administration of temulawak extract in artificial feed on the absolute weight growth of gouramy gave insignificant results $(P>0.05)$. The results showed that in the P0 treatment the absolute weight gain was 0.78 grams, the $P 1$ treatment got an absolute weight of 0.58 grams, the $\mathrm{P} 2$ treatment was 0.33 grams, the $\mathrm{P} 3$ treatment was 0.37 grams, and in the $\mathrm{P} 4$ treatment the results showed absolute weight gain of 0.39 grams.

\section{Absolute Length Growth}

Absolute length was the length growth of a test fish during the maintenance period and was expressed by $(\mathrm{cm})$. The test fish were kept for 45 days and the data are presented in Figure 4.1. 


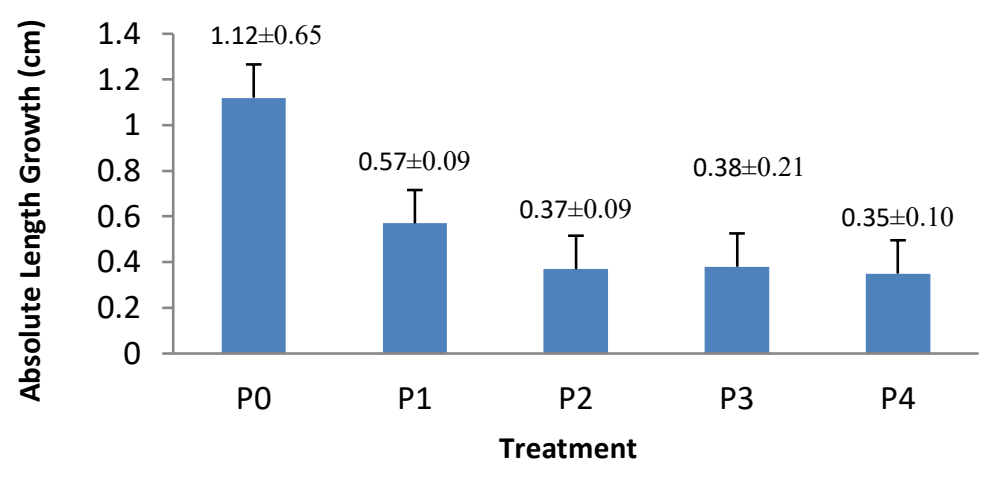

Figure 4.2 Absolute Length of Gourami

Based on the analysis of variance (ANOVA) test results, it was shown that the provision of temulawak in artificial feed on the absolute length growth of gouramy gave insignificant results $(P>0.05)$. The results showed that in the $P 0$ treatment the absolute length added 1.12 $\mathrm{cm}$, the P1 treatment got an absolute length of $0.57 \mathrm{~cm}$, the $P 2$ treatment was $0.37 \mathrm{~cm}$, the P3 treatment was $0.38 \mathrm{~cm}$, and in the P4 treatment the results showed absolute length increment of $0.35 \mathrm{~cm}$.

\section{Feed Efficiency Rate}

The level of feed efficiency was the amount of feed used equal to the weight or amount of fish meat produced. The higher the level of feed efficiency, the better the feed given. The test fish were reared for 45 days and the data on the level of feed efficiency in this study can be seen in Figure 4.3.

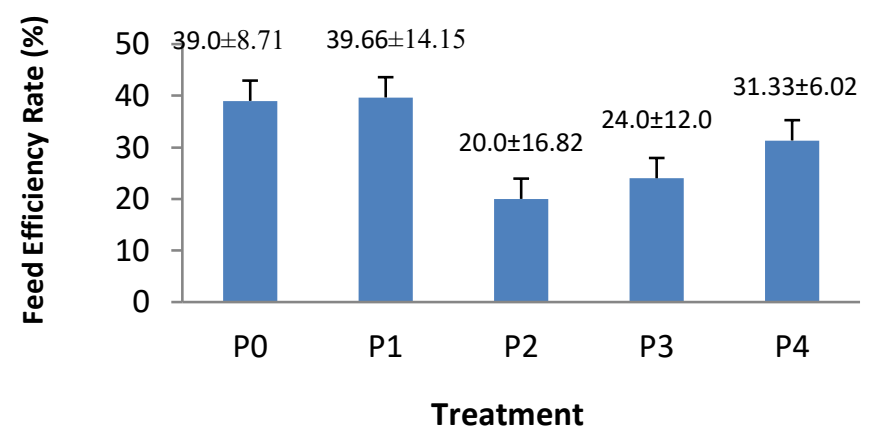

Figure 4.3 Feed Efficiency Level

Based on the analysis of variance (ANOVA) test results, it was shown that the provision of temulwak on artificial feed on the efficiency level of gouramy fish gave insignificant results $(P>0.05)$. The results showed that in the P0 treatment the feed efficiency level was $39.0 \%$, the P1 treatment was $39.66 \%$, the P2 treatment was $20.00 \%$, the P3 treatment was $24.00 \%$, while in the P4 treatment the feed efficiency level was $31.33 \%$.

\section{Survival Rate}

The survival rate was the comparison value between the number of organisms that live at the end of the rearing and the number of organisms at the time of stocking expressed in percent. The data on the survival rate of gouramy in this study are presented in Figure 4.4. 
Journal of Fish Health Vol. 1 (2) - Dec 2021

Ananda et al. (2021)

https://doi.org/10.29303/jfh.v1i2.531

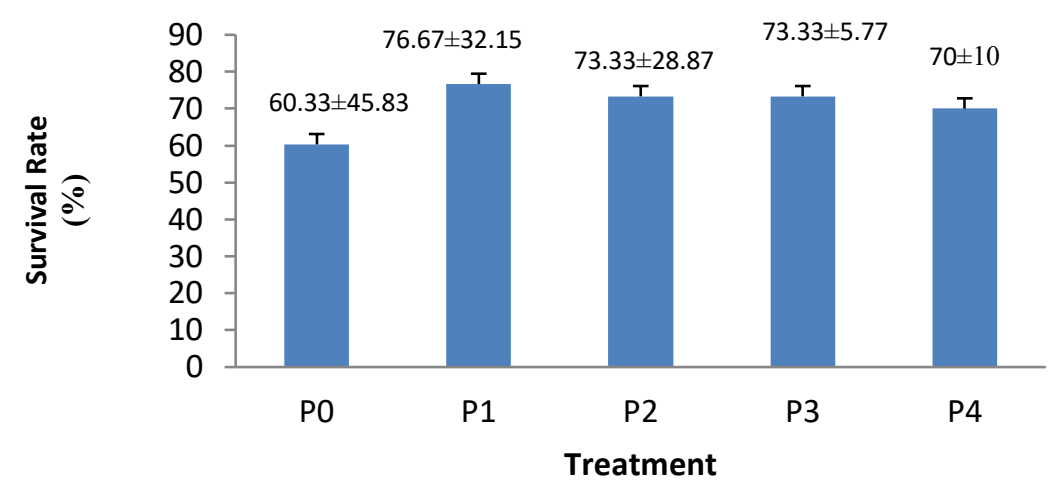

Figure 4.4 Survival Rate

Based on the analysis of variance (ANOVA) test results, it was shown that the provision of temulwak on artificial feed on the survival rate of gouramy gave insignificant results ( $P>0.05$ ). The results showed that the P0 treatment resulted in a survival rate of $60.00 \%$, in the $\mathrm{P} 1$ treatment the survival rate was $76.67 \%$, the $\mathrm{P} 2$ treatment was $73.33 \%$, the $\mathrm{P} 3$ treatment was $73.33 \%$, and the P4 treatment the percentage of survival rate was $70 \%$.

Water Quality

\section{a. Temperature}

Temperature measurements were carried out at the beginning, middle and end of maintenance. Water temperature conditions are expressed in degrees. The results of temperature measurements are presented in Table 3.

Table 3. Temperature measurement results

\begin{tabular}{ccccc}
\hline Treatment & \multicolumn{3}{c}{ Temperature $\left({ }^{\circ} \mathrm{C}\right)$} \\
\cline { 2 - 5 } & Beginning & middle & End & Literature \\
\hline P0 & 27 & $26-27$ & $26-27$ & $24^{\circ} \mathrm{C}-28^{\circ} \mathrm{C}$ Kordi and \\
P1 & 27 & $27-28$ & $26-28$ & Ghufran (2009) in Fitriadi \\
P2 & 27 & $27-28$ & $27-28$ & $(2014)$. \\
& & & & \\
P3 & 27 & $27-28$ & $27-28$ & \\
P4 & 27 & $26-27$ & $26-27$ & \\
\hline
\end{tabular}

From the table above, it can be seen that the water temperature at the beginning of maintenance the temperature measurement value was $27^{\circ} \mathrm{C}$, in the middle of maintenance the water temperature ranges from $26-28^{\circ} \mathrm{C}$, while at the end of maintenance the water temperature ranges from $26-28^{\circ} \mathrm{C}$.

b. Degree of Acidity $(\mathrm{pH})$

The degree of acidity or $\mathrm{pH}$ was a picture that shows the acid or wet conditions of a water used in aquaculture activities. Measurement of $\mathrm{pH}$ in this study was presented in Table 4. 
Journal of Fish Health Vol. 1 (2) - Dec 2021

Ananda et al. (2021)

https://doi.org/10.29303/jfh.v1i2.531

Table 4. Results of $\mathrm{pH}$ measurements

\begin{tabular}{ccccc}
\hline \multirow{2}{*}{ Treatment } & \multicolumn{4}{c}{ Degree of Acidity (pH) } \\
\cline { 2 - 5 } & Beginning & middle & End & Literature \\
\hline P0 & $6.8-6.9$ & 6.5 & 6.5 & \\
P1 & $6.7-6.9$ & 6.5 & 6.5 & 6.5-8 Independent \\
P2 & $6.8-6.9$ & 6.5 & 6.5 & Farmers Work Team \\
P3 & $6.7-6.9$ & 6.5 & 6.5 & $(2009)$ \\
P4 & $6.8-6.9$ & 6.5 & 6.5 & \\
\hline
\end{tabular}

The $\mathrm{pH}$ range of the water at each measurement was obtained results, at the beginning of maintenance the $\mathrm{pH}$ range was in the range of 6.7-6.9. $\mathrm{pH}$ at mid-maintenance was around 6.5. While at the end of maintenance the $\mathrm{pH}$ range was 6.5 .

c. Dissolved Oxygen (DO)

Dissolved oxygen in water was expressed in $\mathrm{mg} / \mathrm{l}$. The dissolved oxygen value in this study was presented in Table 5.

Table 5. Dissolved Oxygen (DO) measurement results

\begin{tabular}{ccccc}
\hline \multirow{2}{*}{ treat } & \multicolumn{4}{c}{ DO (ppm) } \\
\cline { 2 - 5 } & Beginning & middle & End & Literature \\
\hline P1 & 7 & 6.5 & 6.5 & \\
P2 & 7 & 6.5 & 6.5 & $>2$ ppm Independent \\
P3 & 7 & 6.5 & 6.5 & (2009) \\
P4 & 7 & 6.5 & 6.5 & \\
\hline
\end{tabular}

From the results of the study, it was found that the dissolved oxygen measurement results were, at the beginning of the maintenance the dissolved oxygen content was $7 \mathrm{ppm}$, the dissolved oxygen measurement in the middle of the maintenance was $6.5 \mathrm{ppm}$, then the dissolved oxygen measurement was carried out at the end of the maintenance and the measurement results were $6.5 \mathrm{ppm}$.

\section{DISCUSSION}

Based on the results of research on the effect of giving temulwak (Curcuma xanthorriza) to artificial feed on the growth of gouramy (Osphronemus goramy), the parameters observed were: absolute weight, absolute length, survival rate, water quality, and feed efficiency. In the calculation of absolute weight growth, the results show that in treatment P0 the absolute weight gain was 0.78 grams, in treatment $\mathrm{P} 1$ the absolute weight was 0.58 grams, treatment P2 was 0.33 grams, in treatment P3 was 0.37 grams, and in the P4 treatment the absolute weight gain was 0.39 grams. Giving the right dose will support the main function of the additives used and these ingredients can be utilized and can be distributed properly by any method. This was reinforced by Sari et al. (2012), the addition of temulawak extract to feed with various different doses can affect the daily relative growth rate of Tawes fish, this was because the dose and content of curcumin and essential oils can increase bile secretion so 
Journal of Fish Health Vol. 1 (2) - Dec 2021

Ananda et al. (2021)

https://doi.org/10.29303/jfh.v1i2.531

that it can increase fish appetite. Previous studies used an average dose below $14 \%$ per $\mathrm{kg}$ of feed. In this study, it was inversely proportional to previous studies that the use of temulawak extract gave results that were not significantly different. The possibility of using too high a dose above $14 \%$ per $\mathrm{kg}$ of feed and according to Astuti (2017) the dose used may be included in a dose that can not be tolerated by carp. Because the results of this study indicate that the higher the dose used, the lower the results obtained.

In addition to calculating absolute weight growth, calculations were also carried out to determine absolute length growth. The results showed that in the P0 treatment the absolute length added $1.12 \mathrm{~cm}$, the $\mathrm{P} 1$ treatment got an absolute length of $0.57 \mathrm{~cm}$, the P2 treatment was $0.37 \mathrm{~cm}$, the $\mathrm{P} 3$ treatment was $0.38 \mathrm{~cm}$, and in the P4 treatment the results showed absolute length increment of $0.35 \mathrm{~cm}$. The increase in body length of fish was influenced by the amount of feed consumed and the content of feed that fulfills the nutrition of the fish. The addition of temulawak extract with different concentrations in the feed did not affect the absolute length growth of gouramy. If the feed was not used properly by the fish, the body produces insufficient energy for growth, it was suspected that the energy from the consumption of feed that was not optimal was only used for survival. So that the fish do not move optimally so that it affects the length of the fish. Internal factors that affect growth include heredity or genetics, sex, age, resistance to disease. Meanwhile, external factors that influence growth include food, water quality and space (Huet, 1972; Moyle \& Cech, 1982; Effendi, 1997) in Setyowati (2007).

In this study, the growth of fish length was very slow because the function of the extract used did not give a real effect. Judging from the increase in length, the average was still below $0.5 \mathrm{~cm}$ for the length of the fish given the addition of ginger extract. In fact, a fairly good length growth was found in the control treatment with an increase in length of $1 \mathrm{~cm}$. It was possible that the addition of temulawak extract to carp commercial feed can leave the nutritional content of the feed itself so that the nutritional content of the feed was reduced. This was the possibility that makes the feed smell different from the smell of feed which was initially very distinctive, the smell of protein becomes a different smell such as the smell of plants and the color of the feed becomes pale so that the protein content becomes pale. The fish's body converts the protein in the feed into protein according to its needs. Chemically there are two basic processes for protein synthesis, namely the synthesis of amino acids and the conjugation of suitable amino acids to form each type of protein in each cell. This process was the most basic growth because without massive protein production, growth was impossible (Fujaya, 2004 in Winari, 2019). So, it was necessary to pay attention to the efficiency value of the feed given.

The value of feed efficiency was a parameter for determining the quality of the feed given to the growth of carp. The results showed that in the P0 treatment the feed efficiency level was $39.0 \%$, the P1 treatment was $39.66 \%$, the P2 treatment was $20.00 \%$, the P3 treatment was $24.00 \%$, while in the P4 treatment the feed efficiency level was $31.33 \%$. The level of feed efficiency was influenced by the quality and quantity of feed given to the test fish, such as the nutritional content of the feed according to the nutritional needs of the test fish being kept, the feed used was not stored for a long time, causing the feed to become smelly and moldy. It was also supported by the health of the fish (fish are not infected with diseases and defects) and the health of the environment in which the fish are kept, such as the water used that does not contain waste and was in accordance with the water quality standards that are intended. The low value of feed efficiency in this study was thought to be caused by the feed ingredients used have low digestibility, especially materials derived from 
Journal of Fish Health Vol. 1 (2) - Dec 2021

Ananda et al. (2021)

https://doi.org/10.29303/jfh.v1i2.531

plants. Vegetable raw materials are physiologically difficult to digest by carnivorous fish, including carnivorous fish, which in terms of food habits and feeding habits are classified as carnivorous fish. Djarijah (1995) in Hariyadi et al. (2005) in Hidayat (2013), stated that the factors that determine the level of feed efficiency are the type of nutrient source and the amount of each component of the nutrient source in the feed.

Fajri (2015) states that the percentage of the best feed efficiency was in the range of 30$60 \%$. Feed efficiency in this study ranged from $20.54 \%$ to $40.31 \%$ indicating that the feed efficiency value obtained in this study was lower than the value proposed by NRC (1983). NRC (1993) states that feed efficiency was closely related to the preference of fish with the feed given, besides that it was influenced by the ability of fish to digest feed ingredients. Effendie (1997) in Fajri (2015) adds that the preference of organisms for the feed given was influenced by several factors, namely: organism stocking density, feed availability, fish choice factors and physical factors that affect the waters.

Self-feeding not only affects growth in weight and length but also affects the survival of gourami. In their natural habitat, gouramy fish are fish that live in silent streams (low water) and are not very clean. The results showed that the P0 treatment resulted in a survival rate of $60.00 \%$, in the $\mathrm{P} 1$ treatment the survival rate was $76.67 \%$, the $\mathrm{P} 2$ treatment was $73.33 \%$, the P3 treatment was $73.33 \%$, and the P4 treatment the percentage of survival rate was $70 \%$. In this study, water changes that were carried out once a day affected the level of survival of carp that were kept. It was suspected that because of the frequent water changes during the study, the fish became stressed, the brightness of the habitat was too high, so that it could cause the death of the test fish that were kept. Sitanggang and Sarawono (2008) in Thaiin (2016) gourami inhabits calm and stagnant waters such as swamps, lakes and lakes. Gouramy fish are rarely found in waters that have strong currents. In addition, it was important to measure water quality such as temperature, $\mathrm{pH}$ and dissolved oxygen.

The high and low temperature values are influenced by environmental conditions during the maintenance of organisms. The initial water temperature of maintenance in this study obtained the temperature value was $27^{\circ} \mathrm{C}$, mid maintenance the water temperature ranges from $26-28^{\circ} \mathrm{C}$, while at the end of the maintenance the water temperature ranges from 26 $28^{\circ} \mathrm{C}$. Water temperature has a very important effect in the process. respiration, appetite and affect the body's metabolic system. However, this temperature range includes the normal range for the life of salted fish that are kept. Kordi and Ghufran (2009) in Fitriadi (2014) state that fish will grow well in an environment with a water temperature of around $24^{\circ} \mathrm{C}-28{ }^{\circ} \mathrm{C}$.

The $\mathrm{pH}$ range of the water at each measurement was obtained results, at the beginning of maintenance the $\mathrm{pH}$ range was in the range of 6.7-6.9. $\mathrm{pH}$ at mid-maintenance was around 6.5. While at the end of the maintenance, the $\mathrm{pH}$ range was 6.5. The high and low $\mathrm{pH}$ values can inhibit the growth process in betta fish and can even cause death. Water $\mathrm{pH}$ was related to fish respiration, metabolism and so on. If the $\mathrm{pH}$ was too high and too low, it will affect the respiration process, and the fish's metabolism will be disturbed. In this study, the $\mathrm{pH}$ of the waters was still considered optimal for the maintenance of carp. Good water acidity (pH) was between 6.5-8 (Mandiri, 2009).

The high and low dissolved oxygen content in the rearing media causes the fish to become stressed and the fish's appetite will decrease. From Table 5. it can be concluded that the dissolved oxygen content in research activities was fairly normal for the life of carp. According to Mandiri (2009), the oxygen demand for each age and size of fish was different. Fish that are small or still larvae need dissolved oxygen that was not too high because it can make the movement of the larvae become unstable and make the larvae become stressed. Likewise for 
Journal of Fish Health Vol. 1 (2) - Dec 2021

Ananda et al. (2021)

https://doi.org/10.29303/jfh.v1i2.531

fish with a larger age and size, the presence of dissolved oxygen will be higher because the larger the size of the fish, the more oxygen will be needed for its survival.

\section{CONCLUSION}

The conclusion that can be drawn from this study is that the addition of temulawak extract to the commercial feed of carp has no significant effect on absolute weight, absolute length, feed efficiency and survival rate of gourami.

\section{ACKNOWLEDGMENT}

In this opportunity, the author would like to express his gratitude to the Mataram University Program which has accommodated this research.

\section{REFERENCES}

Affandi, R. (1993). Study of eating habits of carp (Osphronemus goramy). Indonesian Journal of Fisheries and Marine Sciences, 1 (2), 56-67.

Agromedia, R. (2007). Complete Guide to Cultivating Gourami. Agromedia Library. Jakarta.

Fajri, MA, Adwelina, Netti, A. (2015). Addition of Probiotics in Feed on Growth and Feed Efficiency of Baung Fish (Hemibagrus mumurus). Journal of the Faculty of Fisheries and Marine Sciences, Riau University. New Week. 1-11.

Fitriadi, MW, Fajar, B., Ristiawan AN (2014). The Effect of Giving Recombinant Growth Hormone (RGH) Through Oral Methods with Different Time Intervals on Survival and Larval Growth of Gurame var Bastard Fish (Osphronemus goramy Lac, 1801). Journal of Aquaculture Management and Technology, 3 (2), 77-85.

Ghufran, M., Kordi, HK (2010). The Smart Book for the Maintenance of 14 Economical Freshwater Fish in Floating Net Cages. Lily Publisher. Yogyakarta.

Hartini, S., Ade, DS, and Ferdinand, HT (2013). Water Quality, Survival and Growth of Snakehead Fish (Channa striata) Seeds Maintained in Media with The Addition of Probiotics. Indonesian Journal of Swamp Aquaculture, 1 (2), 192-202.

Hidayat, D., Ade, DS, Yulisman. (2013). Survival, Growth and Efficiency of Snakehead Fish (Channa stiata) which is fed with gold snail flour (Pamoceasp.) feed as raw material. Indonesian Journal of Swamp Aquaculture, 1 (2), 161-172.

Insana, N., Farhanah, W. (2015). Substitution of Temulawak Flour (Curcuma xanthorriza sp.) In Different Doses of Feed on Growth and Survival of Tilapia (Oreochromis niloticus) Seeds. Journal of Aquaculture Study Program. Faculty of Agriculture. Muhammadiyah University of Makassar, 4 (2).

Mandiri, TKT (2009). Gurami Cultivation Guidelines Livestock Cultivation Series. Aulia nuance. Margahayu Permai, Bandung.

Prabowo, AS, Beni, DM, Tri, YM (2017). Effect of Addition of Temulawak to Artificial Feed on Milkfish Growth. Journal of Aquatic PEN, 15(1).

Sari, RM, Yilisman, Muslim. (2015). Growth Rate and Survival of Betok Fish (Anabas testudineus) Larvae at Various Feed Change Periods. Indonesian Journal of Swamp Aquaculture, 3 (1), 70-81. 
Sari, NW, lesje, L., Nety, A. (2012). The Effect of Giving Temulawak (Curcuma xanthorriza Roxb) on the Survival of Carp (Ciprinus carprio L) after being infected with Aeromonas hydropila. Journal of Fisheries and Marine Affairs, 7 (2).

Setyo, A., P, Benny, D., M, Tri Y., M. (2017). Effect of Addition of Temulawak (Curcuma xanthorriza) to Artificial Feed on the Growth of Milkfish (Chanos chanos). Journal of Aquatic Pens, 15 (1).

Setyowati, N., Ign, H., Susilo BP (2007). Survival and Post-Larval Seed Growth of Several Subspecies of Gourami (Osphronemus goramy). Journal of Fisheries (J. Fish. Sci), 9 (1), 149-153.

Sulatika, IGB, I Wayan R., Endang, WS (2019). Effect of Different Protein Levels on Juvenile Growth Rate of Gouramy (Osphronemus gouramy) in Tarpaulin Ponds. Journal of Current Trends in Aquatic Science, 2 (1),5-12.

Thaiin, A. (2016). Effect of Lysine Administration in Commercial Feed on Energy Retention and Feed Conversion Ratio of Gourami (Osphronemus goramy). Essay. Faculty of Fisheries and Marine Science. Airlangga University. Surabaya. 